\title{
STUDI LITERATUR DOUBLE LOOP PROBLEM SOLVING (DLPS) TERHADAP KEMAMPUAN PEMECAHAN MASALAH IPA SISWA SMP
}

\author{
Silva Ayu Indah Permata ${ }^{1}$, Widha Sunarno ${ }^{2}$ dan Harlita $^{3}$ \\ ${ }^{1}$ Program Studi Magister Pendidikan Sains, FKIP, Universitas Sebelas Maret \\ Surakarta, 57126, Indonesia \\ Email: ${ }^{1}$ silva05@ @ student.uns.ac.id; ${ }^{2}$ widhasunarno@ staff.uns.ac.id; ${ }^{3}$ harlita@staff.uns.ac.id \\ Diajukan: 10 Agustus 2021; Diterima: 29 September 2021; Diterbitkan: 30 Oktober 2021
}

\begin{abstract}
Abstrak: Penelitian ini membahas berbagai literatur tentang model Double Loop Problem Solving (DLPS) sebagai solusi ketika mengembangkan kemampuan siswa SMP dalam memecahkan permasalahan. Instrumen dalam penelitian ini menggunakan tes wawancara untuk guru dan siswa kelas VII SMPN 3 Singosari. Berdasarkan wawancara memperlihatkan kemampuan siswa tergolong rendah ketika memecahan masalah. Terlihat dari prilaku siswa yang pasif ketika proses pembelajaran berlangsung. Kebanyakan siswa berasumsi materi IPA adalah materi yang sulit dipahami, dan membosankan. Hal tersebut terjadi karena siswa ketika proses pembelajaran berlangsung hanya mendengarkan saat guru menjelaskan dan tidak terlibat langsung dalam mengkaji materi yang dipelajari. Guru dalam proses pembelajaran telah menyesuaikan kurikulum 2013 dengan menerapkan model pembelajaran discovery learning, tetapi pada prosesnya guru hanya berceramah ketika menjelaskan materi. Metode yang digunakan adalah studi literatur dan wawancara. Berdasarkan hasil studi literatur dibutuhkan solusi untuk mengatasi masalah tersebut adalah dengan penerapan model pembelajaran Double Loop Problem Solving.
\end{abstract}

Kata kunci: IPA, double loop problem solving, kemampuan pemecahan masalah

\begin{abstract}
This study discusses various literatures on the Double Loop Problem Solving (DLPS) model as a solution when developing the ability of junior high school students to solve problems. The instrument in this study used an interview test for teachers and students of class VII SMPN 3 Singosari. Based on interviews, it shows that students' abilities are low when solving problems. It can be seen from the passive behavior of students when the learning process takes place. Most students assume that science material is difficult to understand and boring material. This happens because students when the learning process takes place only listen when the teacher explains and are not directly involved in reviewing the material being studied. The teacher in the learning process has adjusted the 2013 curriculum by applying the discovery learning model, but in the process the teacher only lectures when explaining the material. The method used is literature study and interviews. Based on the results of the literature study, a solution to overcome this problem is needed by applying the Double Loop Problem Solving learning model.
\end{abstract}

Keywords: science, double loop problem solving, problem solving ability

\section{Pendahuluan}

Model pembelajaran Double Loop Problem Solving (DLPS) adalah salah satu model pembelajaran yang mampu mengasah kemampuan berpikir siswa. Model DLPS merupakan model pembelajaran berbasis masalah yang berfokus pada pencarian penyebab permasalahan (Arum, 2017). Menurut Widiawati, Susongko \& Widiyanto (2019) model pembelajaran DLPS adalah pengembangan pembelajaran dari model pembelajaran berbasis masalah yang menekankan pada pencarian penyebab utama dari timbulnya masalah.
DLPS merupakan salah satu dari model pembelajaran kooperatif yang berpengaruh positif terhadap proses belajar terutama pada peningkatan kemampuan pemecahan masalah siswa. Penerapan model pembelajaran DLPS selain mampu meningkatkan kemampuan pemecahan masalah mampu meningkatkan kemampuan berpikir kritis, meningkatkan kualitas pembelajaran, hasil belajar, dan prestasi belajar siswa. Model pembelajaran DLPS menekankan bagi siswa untuk mampu aktif dalam proses pembelajaran (Pratama, 2018).

Model pembelajaran DLPS banyak digunakan sebagai model pembelajaran yang mengajak siswa aktif dalam kegiatan 
pembelajaran. (Nizaar \& Putra, 2016). Model DLPS menuntut siswa harus aktif melakukan kegiatan, aktif berpikir, aktif menyusun konsep dan memberi makna mengenai sesuatu yang sedang dipelajari, sehingga meningkatkan pemahaman konsep yang digunakan dalam penyelesaiaan masalah dan meningkatkan hasil belajar siswa (Safitri \& Zen, 2018).

Model DLPS dikenal dengan metode pengambilan keputusan yang melibatkan proses mempertimbangkan berbagai pilihan alternatif solusi yang akhirnya akan sampai pada kesimpulan yang akan digunakan (Nizaar \& Putra, 2016). Kegiatan pembelajaran menggunakan model DLPS mampu memberikan kesempaan bagi siswa untuk memperoleh pengetahuan, pengalaman, menemukan, dan mengenali berbagai alternatif solusi (Safitri \& Zen, 2018). Menurut Jufri (2015) model DLPS berfokus pada pengambilan keputusan yang dibuat melalui informasi yang dikumpulkan, menafsirkan informasi yang diperoleh, dan memanfaatkan informasi.

Ciri utama dalam proses pembelajaran model DLPS adalah pemberian masalah yang nantinya akan dianalisis siswa untuk mencari solusi, sehingga mampu melatih siswa untuk berpikir kritis dan kreatif (Nizaar \& Putra, 2016). Pembelajaran menggunakan model DLPS dimulai dengan menganalisis masalah, mencari penyebab timbulnya masalah, menganalisis penyebab dan menyelesaikan masalah sesuai dengan analisis yang telah dilakukan (Fatmala, Dwijananti, \& Astuti, 2016). Proses penyelesaian masalah pada model DLPS terjadi melalui dua loop pemecahan masalah yang berbeda, loop pertama mendeteksi penyebab langsung sedangkan loop kedua mendeteksi penyebab yang tingkatnya lebih tinggi, meskipun kedua loop berbeda tetapi keduanya saling terkait (Nizaar \& Putra, 2016).

Pada akhirnya pembelajaran dengan menerapkan model DLPS dapat meninggalkan kesan yang baik dalam diri siswa dan mampu memberikan pengalaman belajar yang bermakna bagi siswa kedepannya dan mampu meningkatkan kemampuan pemecahan masalah siswa (Nizaar \& Putra, 2016).

Kemampuan pemecahan masalah merupakan kemampuan menggunakan informasi untuk memilih apa yang harus dilakukan dalam suatu keadaan tertentu (Oktaviani \& Tari, 2018). Kemampuan pemecahan masalah sangat penting, karena siswa akan dibawa pada permasalahan yang tidak dapat ditemukan jalan keluarnya secara langsung, baik permasalahan pada kelas atau permasalahan yang dijumpai pada kehidupan sehari-hari (Dwijowati Asih Saputri dan Selfy Febriani, 2017).

Proses memecahkan masalah membutuhkan kemampuan pengorganisasian strategi. Kemampuan pengorganisasian strategi mampu membuat siswa berpikir secara logis, kreatif dan kritis dalam menghadapi kehidupan di sekitarnya (Fauziah, 2005). Kemampuan pemecahan masalah memunculkan budaya berpikir pada jiwa siswa karena mereka dituntut untuk berpikir kritis dan analitis (Afcariono, 2008). Indikator kemampuan pemecahan masalah dapat di lihat pada Tabel 1.

Tabel 1. Indikator Kemampuan Pemecahan Masalah

\begin{tabular}{|c|c|}
\hline $\begin{array}{c}\text { Kemampuan } \\
\text { PemecahanMasalah }\end{array}$ & Indikator \\
\hline $\begin{array}{l}\text { Mengidentifikasi } \\
\text { masalah }\end{array}$ & $\begin{array}{l}\text { - Menyebutkan fakta terkait } \\
\text { masalah } \\
\text { - Menentukan konsep atau kategori } \\
\text { - Mencari informasi/data yang } \\
\text { sesuai dengan permasalahan } \\
\text { - Menentukan tempat, waktu, dan } \\
\text { pelaku dalam permasalahan yang } \\
\text { disajikan }\end{array}$ \\
\hline Memeriksa masalah & $\begin{array}{l}\text { - Mengidentifikasi penyebab utama } \\
\text { masalah. } \\
\text { - Memeriksa hubungan timbal } \\
\text { balik yang terdapat dalam } \\
\text { permasalahan } \\
\text { - Memeriksa seberapa parah } \\
\text { permasalahan yang dihadapi } \\
\text { - Memeriksa solusi yang pernah } \\
\text { dilakukan }\end{array}$ \\
\hline Merencanakan solusi & $\begin{array}{l}\text { - Mengembangkan rencana untuk } \\
\text { menyelesaikan permasalahan } \\
\text { - Memetakan masalah dan solusi } \\
\text { - Memilih teori yang digunakan } \\
\text { untukmemecahkan masalah }\end{array}$ \\
\hline $\begin{array}{l}\text { Merencanakan } \\
\text { rencana yang telah } \\
\text { dibuat }\end{array}$ & $\begin{array}{l}\text { - Membuat daftar permasalahan } \\
\text { yang akan diselesaikan } \\
\text { - Mengurutkan langkah-langkan } \\
\text { untuk menyelesaikan } \\
\text { permasalahan } \\
\text { - Menentukan pihak yang terlibat } \\
\text { dalam proses penyelesaian } \\
\text { masalah }\end{array}$ \\
\hline Mengevaluasi & $\begin{array}{l}\text { - Memeriksa kembalisolusi yang } \\
\text { telah dibuat } \\
\text { - Membuat dugaan mengenai } \\
\text { solusi yang dibuat }\end{array}$ \\
\hline
\end{tabular}




\begin{tabular}{ll}
\hline - & Memperkirakan hasil dari proses \\
pemecahan masalah \\
- Memilih media yang tepat untuk \\
mengkomunikasikan hasil \\
pemecahan masalah.
\end{tabular}

(Fatmala et al., 2016).

Siswa dengan kemampuan memecahkan masalah akan terlatih ketika menemukan tantangan, menghasilkan ide serta memilih banyak ide untuk dipakaikan sebagai solusi dari masalah yang dihadapi (Hooijdonk, Mainhard, Kroesbergen, \& Tartwijk, 2020). Kemampuan siswa dalam memecahkan masalah sangat penting, karena siswa akan disajikan permasalahan yang tidak bisa diselesaikan secara langsung, baik permasalahan di dalam kelas atau dalam kehidupan sehari-hari, sehingga kemampuan pemecahan masalah dianggap sebagai bagian mendasar dari pembelajaran IPA (Dwijowati Asih Saputri dan Selfy Febriani, 2017).

Ilmu Pengetahuan Alam (IPA) salah satu ilmu yang pusat pembahasannya adalah alam serta proses yang terjadi di dalamnya (Widowati, 2008). IPA berkaitan dengan bagaimana proses megetahui tentang gejala alam secara terstruktur, sehingga tidak hanya memahami pengetahuan, prinsip, fakta, atau konsep namun juga proses penemuannya dan pembentukan sikap ilmiah (Tursinawati, 2013).

Pembelajaran IPA erat kaitannya dengan proses mengamati, memahami, menganalisis masalah dan menyelesaikan masalah agar bermanfaat untuk kehidupan. Pembelajaran IPA yang ditemukan di beberapa sekolah hanya sebatas memahami konsep, seharusnya pembelajaran IPA mampu meninjau pada keterampilan proses, konsep, aplikasi isu, dan mampu menanamkan jiwa keingintahuan pada siswa (Oktaviani \& Tari, 2018).

Tujuan pembelajaran IPA di SMP atau MTs diantaranya peserta didik mempunyai keterampilan menguraikan tentang berbagai gejala alam, konsep, dan prinsip IPA yang berguna dan dapat diaplikasikan untuk kehidupan nyata (Departemen Pendidikan Nasional, 2006). Pembelajaran IPA difokuskan pada pembangunan pengetahuan siswa secara mandiri. Pembangunan pengetahuan siswa secara mandiri dapat dilakukan dengan menjadikan siswa sebagai pelaku utama pembelajaran, yang aktif membangun pengetahuannya sendiri, bukan menghafal konsep melainkan lebih pada menemukan konsep menjadikanya seorang yang kritis, kreatif serta bisa memecahkan masalah yang ditemui pada pembelajaran IPA dan aplikasinya (Oktaviani \& Tari, 2018).

Kemampuan siswa untuk memecahkan masalah dapat dimiliki apabila guru membiasakannya melalui proses pembelajaran (Pratiwi \& Nurita, 2016). Proses pembelajaran yang dirancang harus mampu mengubah kegiatan yang berorientasi menghafal menjadi kegiatan yang berorientasi untuk menemukan konsep dan memecahkan masalah pada pelajaran yang ada kaitannya dengan kehidupan seperti IPA.

Hasil observasi dari wawancara menunjukkan kemampuan pemecahan masalah di SMPN 3 Singosari kelas VII pada mata pelajaran IPA tergolong rendah, siswa masih kesulitan dalam menemukan, memahami dan mengaplikasikan konsep IPA. Pembelajaran yang berlangsung hanya sebatas memberi tahu siswa mengenai teori, fakta, konsep, dan hukum tentang IPA sehingga mengakibatkan lemahnya kemampuan siswa dalam berpikir sehingga menyebabkan kemampuan siswa ketika memecahkan masalah menjadi rendah.

Hasil wawancara dengan guru IPA di SMPN 3 Singosari terdapat beberapa gejala umum yang menyebabkan kemampuan siswa untuk memecahkan masalah masih terbilang rendah, yaitu sebagai berikut. Pada saat pembelajaran, siswa hanya mampu menerima informasi dari guru tanpa memiliki niat untuk memperoleh informasi sendiri perihal materi yang diajarkan. Hal tersebut terjadi karena saat pembelajaran siswa tidak terbiasa dihadapkan pada permasalahan. Siswa juga masih kesulitan ketika mengaitkan materi yang dipelajari dengan pengalaman nyata. Pernyataan tersebut dapat dibuktikan melalui aktivitas belajar siswa yang kurang terlibat aktif dalam bertanya dan menyampaikan pendapat.

Laporan TIMSS (Trends in International Mathematics and Science Study) memaparkan sebagian besar siswa di Indonesia berada pada tingkatan ke-dua dari enam tingkatan taksonomi bloom, hal tersebut menandakan bahwa kemampuan siswa di Indonesia dalam berpikir logis dan rasional masih rendah (Sucipto, 2017). Data PISA (Program for International Student Assessment) tahun 2018 menyatakan kemampuan sains siswa Indonesia 
berada di peringkat 70 dari 78 negara. Siswa di Indonesia rata-rata hanya mampu mengenali penjelasan dan mengidentifikasi fenomena yang sudah ada serta mampu mencari kebenaran informasi dari data yang diberikan, berdasarkan hasil studi tersebut menunjukkan kemampuan pemecahan masalah siswa di Indonesia masih tergolong rendah. Penelitian yang dilakukan Oktaviani \& Nirmala (2018) ketika pembelajaran berlangsung, siswa hanya menghafal apa yang ada di buku dan pembelajaran nya masih berfokus pada nilai, bukan proses, al tersebut menjadikan kemampuan siswa untuk memecahkan permasalahan masih kurang terlatih.

Melalui permasalahan tersebut, maka perlu diadakan pembaharuan pada proses pembelajaran IPA untuk memberi peluang siswa terlibat aktif, interaktif sehingga mampu meningkatkan kemampuan pemecahan masalahan siswa.

\section{Metode}

Penelitian yang dilakukan bersifat deskriptif. Metode penelitian ini menggunakan wawancara dan studi literatur untuk mencari solusi dari permasalahan rendahnya kemampuan siswa dalam memecahkan masalah kelas VII SMPN 3 Singosari. Instrumen yang digunakan ialah tes wawancara untuk guru IPA dan siswa kelas VII SMPN 3 Singosari.

\section{Hasil dan Pembahasan \\ Hasil}

Dari hasil wawancara dengan guru, mengungkapkan kemampuan memecahkan masalah siswa masih tergolong rendah. Dibuktikan melalui respon siswa yang hanya diam apabila diberi pertanyaan oleh guru. Kebanyakan siswa hanya mampu menjawab pertanyan yang jawabannya ada di buku sehingga mereka hanya menyalin apa yang mereka baca. Siswa juga terlihat pasif karena dalam pembelajaran mereka hanya diam dan mendengarkan guru menjelaskan tanpa terlibat secara langsung untuk menemukan suatu konsep yang dipelajari. Guru telah mencoba menerapkan model pembelajaran discovery learning, tetapi belum mampu membuat siswa aktif ketika proses pembelajaran.

Berdasarkan hasil wawancara terhadap siswa, kebanyakan dari mereka beranggapan bahwa materi IPA adalah materi yang sulit dipahami. Pembelajaran yang dilakukan membuat mereka bosan. Saat pembelajaran siswa cenderung mengantuk terutama pada materi yang abstrak dan tidak bisa diamati secara langsung. Hal tersebut menyebabkan tujuan pembelajaran kurang tercapai. Demi tercapainya tujuan pembelajaran, pemilihan media dan model pembelajaran sangat diperlukan. (Falahudin, 2014).

\section{Pembahasan}

Setelah dilakukan studi literatur dan wawancara dengan guru IPA di SMPN 3 Singosari, pembelajaran IPA membutuhkan pembaharuan model pembelajaran yang disesuai dengan kondisi yang dialami siswa. Model pembelajaran harus dapat membantu siswa terlibat aktif dan mampu meningkatan kemampuan pemecahan masalah siswa sehingga tujuan pembelajaran bisa tercapai.

\section{A. Penerapan Model Pembelajaran Double Loop Problem Solving (DLPS) untuk Meningkatkan Kemampuan Pemecahan Masalah Siswa}

Hasil wawancara menunjukkan kurang aktifnya siswa dalam proses pembelajaran menyebabkan kemampuan pemecahan masalah siswa rendah, karena pemilihan model yang kurang sesuai. Model pembelajaran yang sering digunakan guru adalah model pembelajaran konvensional yang fokusnya adalah mentransfer pengetahuan ke siswa. Proses pembelajaran seperti ini adalah pembelajaran yang berfokus pada guru, guru bertugas sebagai pemberi materi dan siswa hanya mendengarkan penjelasan guru, hal tersebut menyebabkan siswa pasif, kurang tertarik dalam proses pembelajaran, dan siswa kurang mampu menjawab pertanyaan yang diberikan guru sehingga tujuan pembelajaran tidak tercapai.

Beberapa guru telah menyadari perlu adanya pembaruan proses pembelajaran dengan pemilihan model yang sesuai sehingga siswa dapat terlibat laangsung dalam proses pembelajaran. Guru sudah mencoba menerapkan model pembelajaran yang disesuaikan dengan kurikulum 2013 yaitu model discovery learning, tetapi pada pengaplikasiannya guru tetap menyampaikan materi dengan berceramah sehingga siswa cenderung pasif, mengalami kesulitan dalam memahami materi, tidak mampu 
menumbuhkan keterampilan berpikir, dan belum mampu memecahkan permasalahan. Oleh karena itu guru perlu memilih model pembelajaran dan merancang kegiatan pembelajaran yang mampu melibatkan siswa dalam proses pembelajaran.

Pemilihan model pembelajaran merupakan hal yang penting dan harus dipahami karena setiap model pembelajaran mengarah pada desain pembelajaran untuk mencapai tujuan pembelajaran (Safitri \& Zen, 2018). Pemilihan model pembelajaran harus dikembangkan sesuai kebutuhan siswa, membuat siswa terlibat aktif sehingga dapat menjadi alternatif dalam menyelesaikan masalah rendahnya kemampuan siswa ketika memecahkan permasalahan saat pembelajaran IPA. Pembelajaran IPA wajib memfasilitasi siswa mengkonstruk pengetahuannya sendiri, berpikir kritis, dan mampu memecahkan permasalahan dalam pembelajaran IPA yang nantinya akan mereka aplikasikan pada pemecahan masalah dalam dunia nyata (Oktaviani \& Tari, 2018). Guru harus menggunakan model pembelajaran yang efektif sehingga mampu mencapai tujuan pembelajaran (Harsoyo, M. Sopya, 2014).

Berdasarkan permasalahan yang ditemukan, pembelajaran yang diperlukan oleh siswa SMPN 3 Singosari merupakan pembelajaran berbasis masalah. Model pembelajaran yang dapat mengajak siswa aktif disetiap tahapan sangat diperlukan agar siswa terlatih untuk berpikir dan menyampaikan pendapatnya di kelas. Model pembelajaran yang membagikan peluang siswa agar aktif, kritis, kreatif, inovatif, dan menyenangkan mampu membangun siswa mejadi lebih tertarik serta tidak jenuh saat pembelajaran berlangsung. Rendahnya keterampilan siswa ketika mengaitkan materi pembelajaran dengan pengalaman nyata juga menjadi faktor penyebab kurang tercapainya tujuan pembelajaran (Sugandi, 2016).

Kemampuan pemecahan masalah mampu mengasah siswa agar lebih peka, kritis dan kreatif ketika menghadapi permasalahan (Supiyati, Hidayati, Rosidi, Yuniasti, \& Wulandari, 2019). Siswa dalam memecahkan masalah membutuhkan pemahaman dan pengetahuan yang cukup sehingga mampu menemukan solusi dari permasalahan yang dihadapi (Widiawati, Susongko, \& Widiyanto,
2019). Untuk itu pembelajaran IPA memerlukan model pembelajaran yang mampu menekankan pada aspek tersebut. Salah satu yang sesuai untuk diterapkan dalam permasalahan diatas yaitu dengan menerapkan model Double Loop Problem Solving (DLPS).

DLPS merupakan model pembelajaran yang dikembangkan dari model pembelajaran problem solving (Pratama, 2018). Model DLPS fokus pada penemuan sebab dari permasalahan yang mengharuskan siswa berpikir degan sistematis dan logis. Siswa yang dapat mendeteksi penyebab dari suatu permasalahan akan mudah untuk menemukan solusi dari permasalahan yang dihadapi (Ahied \& Rosidi, 2020) . Pengaplikasian model pembelajaran DLPS mampu memperbaiki kualitas pembelajaran serta meningkatkan kemampuan memecahkan masalah sehingga hasil belajar siswa akan meningkat (Pratama, 2018).

Proses pembelajaran model DLPS melibatkan siswa aktif dalam pembelajaran dan mengharuskan siswa menemukan alasan timbulnya masalah dari permasalahan yang dihadapi (Pratama, 2018). Model pembelajaran DLPS dalam prosesnya memiliki dua loop pemecahan masalah. Loop 1 digunakan dalam pencarian penyebab langsung dari permasalahan kemudian merencanakan serta mengaplikasikan solusi sementara. Loop 2 digunakan dalam mendeteksi akar permasalahan, merencanakan kemudian mengaplikasikan sebagai solusi akhir (Nizaar \& Putra, 2016).

Pembelajaran menggunakan model DLPS mampu memudahkan siswa dalam mengaitkan materi yang diajarkan dengan masalah nyata untuk diaplikasikan dalam kehidupan sehari-hari. Siswa akan terbiasa mengaitkan informasi lama dengan informasi baru untuk membangun pengetahuannya sendiri dan mampu menyelesaikan masalah yang sedang dihadapi. Sehingga proses pembelajaran akan lebih bermakna, sehingga tujuan pembelajaran akan tercapai (Ahied \& Rosidi, 2020).

Kelebihan model pembelajaran DLPS menurut Jufri (2015) yaitu;

a) Mampu memperbaiki kemampuan pemecahan masalah siswa sehingga hasil belajar meningkat.

b) Mampu lebih menciptakan suasana belajar ilmiah dan membiasakan siswa 
melangsungkan penelitian untuk memperbaiki proses pembelajaran.

Model pembelajaran DLPS menekankan mengenai pengumpulan informasi, menguraikan informasi, memanfaatkan informasi dengan baik dan memberi peluang siswa mendapatkan pengetahuan dan menemukan macam-macam pilihan solusi dari permasalahan (Jufri, 2015). Langkah-langkah model pembelajaran DLPS dapat dilihat pada Tabel 1.

Tabel 1. Langkah-langkah Pembelajaran DLPS

\begin{tabular}{|c|c|c|}
\hline Sintaks & Keterangan & Kegiatan Guru \\
\hline $\begin{array}{l}\text { Mengidentifikas } \\
\text { i masalah }\end{array}$ & $\begin{array}{l}\text { Berpikir dan } \\
\text { mencari segala } \\
\text { sesuatu yang } \\
\text { menjadi faktor } \\
\text { dari permasalahan }\end{array}$ & $\begin{array}{l}\text { Menstimulus dan } \\
\text { memperkenalkan } \\
\text { siswa dengan } \\
\text { masalah }\end{array}$ \\
\hline $\begin{array}{l}\text { Mendeteksi } \\
\text { penyebab } \\
\text { langsung }\end{array}$ & $\begin{array}{l}\text { Menentukan } \\
\text { penyebab } \\
\text { langsung } \\
\text { permasalahan dan } \\
\text { membuat solusi } \\
\text { sementara }\end{array}$ & $\begin{array}{l}\text { Membantu siswa } \\
\text { dalam } \\
\text { menentukan } \\
\text { penyebab } \\
\text { langsung } \\
\text { permasalahan dan } \\
\text { membuat solusi } \\
\text { sementara }\end{array}$ \\
\hline $\begin{array}{l}\text { Mengevaluasi } \\
\text { keberhasilan } \\
\text { dari solusi } \\
\text { sementara }\end{array}$ & $\begin{array}{l}\text { Mengevaluasi } \\
\text { seberapa besar } \\
\text { keefektifan dan } \\
\text { tingkat } \\
\text { keberhasilan dari } \\
\text { solusi sementara }\end{array}$ & $\begin{array}{l}\text { Membantu siswa } \\
\text { dalam } \\
\text { mengevaluasi } \\
\text { keberhasilan dari } \\
\text { solusi sementara }\end{array}$ \\
\hline $\begin{array}{l}\text { Menentukan } \\
\text { apakah } \\
\text { diperlukan } \\
\text { analisis akar }\end{array}$ & $\begin{array}{l}\text { Mempertimbangk } \\
\text { an hasil evaluasi } \\
\text { yang dilakukan } \\
\text { sebelumnya } \\
\text { apakah cukup atau } \\
\text { perlu } \\
\text { menganalisis akar } \\
\text { masalah }\end{array}$ & $\begin{array}{l}\text { Membantu siswa } \\
\text { menentukan } \\
\text { apakah diperlukan } \\
\text { analisis akar } \\
\text { masalah }\end{array}$ \\
\hline $\begin{array}{l}\text { Mendeteksi } \\
\text { akar masalah } \\
\text { (jika } \\
\text { diperlukan) }\end{array}$ & $\begin{array}{l}\text { Memeriksa } \\
\text { kembali penyebab } \\
\text { permasalahan } \\
\text { yang lebih } \\
\text { mendalam dari } \\
\text { pemicu masalah } \\
\text { yang telah } \\
\text { diketahui } \\
\text { sebelumnya }\end{array}$ & $\begin{array}{l}\text { Membatu siswa } \\
\text { mendeteksi } \\
\text { penyebab } \\
\text { masaalah yang } \\
\text { lebih tinggi } \\
\text { levelnya }\end{array}$ \\
\hline $\begin{array}{l}\text { Merancang } \\
\text { solusi akar } \\
\text { masalah }\end{array}$ & $\begin{array}{l}\text { Menyimpulkan } \\
\text { hasil solusi yang } \\
\text { dapat } \\
\text { menyelesaikanma } \\
\text { salah hingga } \\
\text { tuntas }\end{array}$ & $\begin{array}{l}\text { Membantu siswa } \\
\text { menyimpulkan } \\
\text { solusi dari } \\
\text { permasalahan }\end{array}$ \\
\hline
\end{tabular}

(Modifikasi Jufri, 2015)

Model pembelajaran DLPS mampu meningkatkan kemampuan pemecahan masalah siswa melalui langkah-langkah dalam proses pembelajarannya. Langkah-langkah proses pembelajaram model DLPS dijelaskan sebagai berikut:
1) Mengidentifikasi masalah, pada tahap ini siswa diberikan permasalahan kemudian mereka mencari atau mendeteksi segala sesuatu terkait fakta dari permasalahan dan faktor penyebab masalah,

2) Mendeteksi penyebab langsung, siswa akan mencari penyebab langsung yang mudah terdeteksi dari permasalahan yang sedang dihadapi kemudian mencari solusi yang dapat diterapkan sesuai penyebab langsung yang ditemukan,

3) Mengevaluasi solusi sementara, tahap ini siswa akan berdiskusi mempertimbbangkan kembali seberapa besar keefektifan dan keberhasilan solusi sementara yang telah di buat,

4) Memutuskan untuk menganalisis akar masalah atau tidak, setelah mengevaluasi solusi sementara siswa akan mempertimbangkan hasil evaluasi dan memutuskan apakah sudah cukup atau memerlukan analisis lebih lanjut untuk mendeteksi akar masalah,

5) Mendeteksi akar masalah jika di butuhkan, pada tahap ini siswa akan mencari faktor atau penyebab masalah yang tingkatannya lebih tinggi dari penyebab masalah yang telah dideteksi sebelumnnya,

6) Merancang solusi akar masalah, siswa pada tahap ini akan merancang solusi, solusi yang dirancang bukan lagi solusi sementarai tetapi solusi akhir yang mampu menyelesaikan permasalahan hingga tuntas.

Enam tahapan langkah-langkan di atas mampu membantu dan membiasakan siswa dalam memecahkan permasalahan yang dihadapi. Hal tersebut sesuai dengan fungsi penerapan model pembelajaran DLPS yang dapat membiasakan siswa mengelola pengetahuan yang mereka miliki dengan informasi baru sehingga mampu melakukan proses pemecahan masalah dan mampu mengambil keputusan untuk menyelesaikan permasalahan yang sedang dihadapi (Widiastika \& Ardana, 2019).

Terdapat beberapa penelitian terdahulu yang relevan dengan penelitian ini dan menunjukkan hasil yang sama, antara lain penelitian yang dilakukan Ramadhana dan amalia (2020), dari penelitiannya dapat disimpulkan bahwa model DLPS dapat meningkatkan kemampuan pemecahan masalah 
pada siswa. Dapat dilihat melalui pencapaian 4 indikator DLPS yaitu, (1) dua indikator berada pada kaulifikasi baik yaitu memahami masalah dan merencanakan penyelesaian yang berada pada kisaran 70-84,9, (2) satu indikator melaksanakan penyelesaian berada pada kualifikasi cukup pada kisaran 55-69,9, (3) satu indikator yang kurang adalah menafsirkan hasil yang diperoleh berada pada kisaran 40-54,9. Dengan demikian DPLS mampu meningkatkan kemampuan pemecahan masalah siswa.

Penelitian dari Ahied \& Rosidi (2020) memperlihatkan perbedaan yang signifikan kemampuan pemecahan masalah sebelum dan sesudah menerima penerapan model DLPS, hal tersebut dapat dilihat melalui rata-rata nilai pretest dan posttest. Rata-rata nilai pretest siswa adalah 50,90 yang tergolong dalam kategori rendah, sedangkan rata-rata nilai posttest siswa adalah $78,23 \%$ dengan keriteria sangat baik. Peningkatan kemampuan pemecahan masalah terjadi karena model DLPS membuat siswa lebih aktif dalam pembelajaran, mampu bekerja sama dengan baik, berdiskusi dalam kelompok, serta membantu siswa mengaitkan materi pembelajaran dengan permasalahan di kehidupan sehari-hari. Hasil kesimpulan dari dua penelitian diatas adalah model pembelajaran Double Loop Problem Solving (DLPS) mampu meningkatkan kemampuan pemecahan masalah pada siswa.

\section{B. Interaksi Model Pembelajaran Double Loop Problem Solving (DLPS) dengaan Kemampuan Pemecahan Masalah Siswa}

Pembelajaran dengan menerapkan model pembelajaran berbasis masalah mampu memberi peluang siswa terlibat aktif, interaktif dalam mencapai tujuan pembelajaran dan memecahkan permasalahan. Model pembelajaran DLPS proses pemecahan masalah yang menekankan pada pencarian penyebab utama dari timbulnya masalah. Proses penerapan model pembembelajaran DLPS dalam memecahkan permasalahan adalah dengan mendorong siswa untuk memecahkan masalah melalui dua loop pemecahan maasalah yang berbeda tetapi saling terkait (Ahied \& Rosidi, 2020).

Model pembelajaran DLPS memiliki enam tahapan yaitu mengidentifikasi masalah, mendeteksi penyebab langsung, mengevaluasi solusi sementara, memutuskan menganalisis akar masalah atau tidak, deteksi akar masalah, dan merancang solusi akhir (Jufri, 2015). Tahapan-tahapan tersebut berinteraksi dengan indikator kemampuan pemecahan masalah. indikator kemampuan pemecahan masalah meliputi mengidentifikasi masalah, memeriksa masalah, merencanakan solusi, merencanakan rencana, dan mengevaluasi (Fatmala et al., 2016). Interaksi tahapan model DLPS dengan indikator kemampuan pemecahan masalah adalah sebagai berikut;

1. Mengidentifikasi masalah dapat melatih kemampuan siswa dalam mengidentifikasi masalah. Pada proses ini siswa akan mengumpulkan fakta dan informasi tterkkait permasalahan sehingga mampu memahami masalah dengan baik,

2. Mendeteksi penyebab langsung dapat melatih kemampuan siswa untuk memeriksa masalah. Siswa akan benar-benar memahami penyebab permasalahan yang dihadapi,

3. Mengevaluasi solusi sementara dapat digunakan untuk mengasah kemampuan merencanakan solusi. Siswa akan mencoba merancang solusi sendiri dari permasalahan,

4. Memutuskan analisis akar masalah atau tidak mampu mengasah kemampuan siswa dalam merencanakan solusi dan merancang solusi. Proses ini siswa menganalisis kembali dan membuat keputusan penyelesaian masalah berdasarkan pemikirannya sendiri,

5. Deteksi akar masalah dapat membiasakan siswa dalam merencanakan rencana solusi. Langkah ini mempengaruhi siswa dalam melaksanakan penyelesaiian masalah serta membantu siswa memperdalam materi yang diajarkan,

6. Merancang solusi dapat mengasah kemampuan siswa dalam mengevaluasi dari penyelesaian masalah yang telah dibuat kemudian memilih solusi yang digunakan untuk menyelesaikan masalah. Langkah ini berhubungan dengan kemampuan siswa memeriksa kembalii jawaban yang telah dimiliki. 


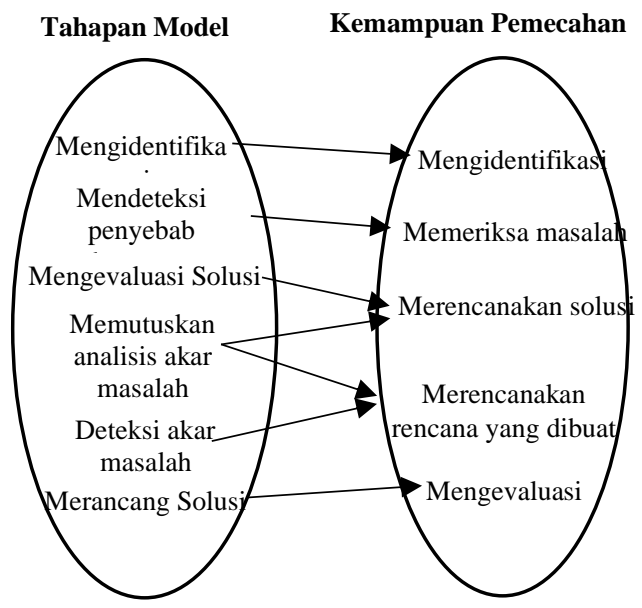

Gambar 1. Analisis keterkaitan model DLPS dengan Indikator Kemampuan Pemecahan masalah

Dari hasil analisis di atas terlihat terdapat interaksi antara model pembelajaran DLPS dengan indikator kemampuan pemecahan masalah. Keterkaitan interaksi model pembelajaran DLPS dapat dilihat pada Gambar 1. Sehingga dapat disimpulkan penerapan model DLPS mempermudah siswa ketika memahami konsep materi pembelajaran dan mampu menerapkan untuk menyelesaikan masalahan (Fatmala et al., 2016).

\section{Kesimpulan dan Rekomendasi}

Berdasarkan hasil dan pembahasan, pengaplikasian model pembelajaran DLPS cocok digunakan dalam peningkatan kemampuan pemecahan masalah siswa. Kegiatan pembelajaran Model DLPS dilakukan dalam dua loop pemecahan masalah yang mampu memberi ruang untuk siswa aktif ketika proses pembelajaran, dan melatih siswa dalam mengaitkan konsep dengan pengalaman nyata, sehingga mampu meningkatkan kemampuan memecahkan masalah.

Peneliti yang ingin melakukan penelitian sejenis sebaiknya melakukan kajian yang mendalam tentang model pembelajaran DLPS dengan menerapkannya pada materi yang karakteristiknnya sesuai dengan model DLPS, selain itu dalam penerapan model DLPS harus mampu manajemen waktu dengan tepat sehingga proses pembelajaran dapat berlangsung lebih efisien dan efektif.

\section{Daftar Pustaka}

Afcariono, M. (2008). Penerapan Pembelajaran
Berbasis Masalah untuk Meningkatkan Kemampuan Berpikir Siswa pada Mata Pelajaran Biologi. Jurnal Pendidikan Inovatif, 3(Nomor 2), 65-68. https://doi.org/10.1039/c5cp04034e

Ahied, M., \& Rosidi, I. (2020). Penerapan Model Pembelajaran Double Loop Problem Solving ( DLPS ) Terhadap Kemampuan Pemecahan Masalah. Jurnal Lumious Riset Ilmiaah Pendidikan Fisika, 1(1), 8-19.

Arum, W. F. (2017). Pengaruh Model Pembelajaran Double Loop Problem Solving dan Problem Posing. Jurnal Teknika STTKD, 4(2), 40-50.

Depdiknas. 2006. Kurikulum Tingkat Satuan Pendidikan: Standar Kompetensi dan Kompetensi Dasar Mata Pelajaran IPA SMP/MTs.Jakarta: Balitbang Depdiknas.

Dwijowati Asih Saputri dan Selfy Febriani. (2017). Pengaruh Model Problem Based Learning $(\mathrm{Pbl}) \quad$ Terhadap Kemampuan Pemecahan Masalah Peserta Didik Pada Mata Pelajaran Biologi Materi Pencemaran Lingkungan Kelas X Mia Sma N 6 Bandar Lampung. Jurnal Tadris Pendidikan Biologi, $8(1), 40-52$.

Falahudin, I. (2014). Pemanfaatan Media dalam Pembelajaran. Jurnal Lingkar Widyaiswara, (4), 104-117.

Fatmala, R. ., Dwijananti, P., \& Astuti, B. (2016). Penerapan Model Double Loop Problem Solving Menggunakan Detektor Geiger Muller untuk Meningkatkan Hasil Belajar Kognitif. Unnes Science Education Journal, 5(3), 1388-1395.

Fauziah, A. (2005). Peningkatan Kemampuan Pemahaman dan Pemecahan Masalah Matematik Siswa SMP Melalui Strategi React. Forum Pendidikan, (1994), 1-13.

Harsoyo, M. Sopya, I. T. (2014). Penerapan Model Pembelajaran Berbasis Masalah dengan Teknik Problem-Prompting untuk Meningkatkan Kemampuan Pemecahan Masalah Siswa Kelas VII SMP. Unnes Physics Education Journal, 3(2).

Hooijdonk, M. Van, Mainhard, T., Kroesbergen, E. H., \& Tartwijk, J. Van. (2020). Creative Problem Solving in Primary Education: Exploring the Role of Fact Finding, Problem Finding, and Solution Finding across Tasks. 
Thinking Skills and Creativity, 37(August 2019), 100665. https://doi.org/10.1016/j.tsc.2020.100665

Jufri, L. H. (2015). Penerapan Double Loop Problem Solving untuk Meningkatkan Kemampuan Literasi Matematis Level 3 pada Siswa Kelas VIII SMPN 27 Bandung. LEMMA Pendidikan Matematika, II(1), 52-62.

Nizaar, M., \& Putra, A. M. (2016). Pengaruh Metode Pembelajaran Double Loop Problem Solving ( DLPS ) Terhadap Hasil Belajar IPS Siswa Kelas VIII SMP Negeri 3 Mataram Tahun Pelajaran 2015-2016. Jurnal Paedagoria, 14(2), 73-77.

Oktaviani, L., \& Tari, N. (2018). Penerapan Model Pembelajaran Berbasis Masalah Untuk Meningkatkan Kemampuan Pemecahan Masalah Ipa Pada Siswa Kelas Vi Sd No 5 Jineng Dalem. Pedagogia Jurnal Ilmu Pendidikan, (5), 9-14.

Pratama, O. I. (2018). Pembelajaran Double Loop Problem Solving Terhadap Kemampuan Pemecahan Masalah Matematis. Desimal Jurnal Matematika, 1(3), 285-291.

Pratiwi, M. D., \& Nurita, T. (2016). Kemampuan Pemecahan Masalah pada Siswa Kelas VII SMP. Jurnal Pensa, (21).

Ramadhana L \& Amalia R. 2018. Pengaruh Model Pembelajaran Double Loop Problem Solving (DPLS) Terhadap Kemampuan Pemecahan Masalah Matematis Siswa SMP. Jurnal Pendidikan Matematika, 6 (2), 210-217.

Safitri, J. A., \& Zen, D. (2018). Pengaruh Model Pembelajaran Double Loop Problem Solving ( DLPS ) Terhadap Hasil Belajar Ranah Kognitif Peserta Didik pada Materi Keanekaragaman Hayati. Jurnal Penelitian Pendidikan Biologi, 2, 41-47.

Sucipto, S. (2017). Pengembangan Ketrampilan Berpikir Tingkat Tinggi dengan Menggunakan Strategi Metakognitif Model Pembelajaran Problem Based Learning. Jurnal Pendidikan (Teori Dan Praktik), 2(1), 77. https://doi.org/10.26740/jp.v2n1.p77-85

Sugandi, M. K. (2016). Peningkatan Kemamppuan Memecahkan Masalah Siswa pada Konsep Ekosistem dengan Pembelajaran Guided Inquiry Berbanuan Audio Visual di Kelas VII SMP IT Hafifudin Arrohimah. Jurnal Bio
Education, 1, 46-54.

Supiyati, H., Hidayati, Y., Rosidi, I., Yuniasti, A., \& Wulandari, R. (2019). Analisis Kemampuan Pemecahan Masalah Siswa Menggunakan Model Guided Inquiry dengan Pendekatan Keterampilan Proses Sains pada Materi Pencemaran Lingkungan. Natural Science Education Reseach, (2018), 59-67.

Tursinawati. (2013). Analisis Kemunculan Sikap Ilmiah Siswa dalam Pelaksanaan Percobaan pada Pembelajaran IPA di SDN Kota Banda Aceh. Jurnal Pionir, 1(1982), 67-84.

Widiastika, M., \& Ardana, N. M. S. M. I. M. (2019). Efektivitas Pendekatan Double Loop Problem Solving dengan Scaffolding dalam Meningkatkan Kemampuan Pemecahan Masalah Matematika. Jurnal Pendidikan Dan Pembelajaran Matematika Indonesia, 8(2), 102-110.

Widiawati, W., Susongko, P., \& Widiyanto, B. (2019). Pembelajaran Model Double Loop Problem Solving Berbantuan Alat Peraga untuk Meningkatkan Kemampuan Literasi Sains Peserta Disi. Jurnal Pendidikan MIPAA PPancasakti, 3, 86-93.

Widowati, Asrih. (2008). Diktat Pendidikan Sains. Yogyakarta: FMIPA UNY. 